\title{
ÁZSIA TÁRGYALKOTÁSA (KÜLÖNÖS TEKINTETTEL A JAPÁN DESIGN EREDMÉNYEIRE) ÉS HATÁSA AZ EURÓPAI FORMAKUL- TÚRÁRA
}

\author{
Marozsán Brigitta \\ Hallgató, Miskolci Egyetem \\ Gép és Terméktervezési Intézet \\ 3515 Miskolc, Miskolc-Egyetemváros, e-mail: zsannalaura @gmail.com \\ Hircsu Mariann \\ Müvésztanár, Miskolci Egyetem \\ Gép és Terméktervezési Intézet \\ 3515 Miskolc, Miskolc-Egyetemváros, e-mail: hircsumariann@ freemail.hu

\section{Sipkás Vivien} \\ PhD hallgató, Miskolci Egyetem \\ Gép és Terméktervezési Intézet \\ 3515 Miskolc, Miskolc-Egyetemváros, e-mail: sipkas.vivien@gmail.com
}

\begin{abstract}
Absztrakt
A 21. század emberét eddig nem tapasztalt termékböség veszi körül, ami a mindennapokban egyszerre jelent pozitívumot és kihivást is. A sokszinüség elönye, hogy mindenki megtalálja személyre szólóan a szükségleteit kielégitö árucikkeket, megfelelö minöségben és árfekvésben is. A tárgyalkotók szempontjából viszont forditottan arányos a helyzet, hiszen az ,árucikkdömping” növekedésével egyre több kritériumnak kell megfelelni. Növekszik az elvárás és egyre nagyobb az igény formavilág, illetve müszaki megoldások tekintetében is egyedi termékek iránt. Tárgyaink nem csak munka-illetve termelöeszközök, hanem müalkotásként az ideológia és a gazdaság része, müszaki, biológiai, szociológiai és esztétikai tényezök optimalizált összessége. A müszaki fejlődés lehetöségeinek köszönhetően az információáramlás időbeli lefolyása minimálisra csökkent, így a fejlődéshez szükséges adatok eljuttatása a világ bármely két pontja között gördülékeny és problémamentes; ez azonban a megfelelö befogadói attitüd nélkül önmagában nem lenne elegendö a tölünk oly távol esö kultúrák kontinenseken átivelö térnyeréséhez.
\end{abstract}

Kulcsszavak: Japán, design, formatervezés, Fukasawa, Tokujon Yoshioka, Mackintosh, japonizmus

\begin{abstract}
21 st century human beings are surrounded by a never experinced amount of products. This means both a positive condition and a challenge in our every day life. The advantage of diversity is that everyone finds individually the fitting products to their needs, in a proper quality and price. From the view of the creators it is the other way round, because with the growing number of goods they have to meet more and more criterias. The expectations are growing and also the need for products which have unique design and technical solutions. Our objects are not only tools or means of production, they are pieces of art as a part of ideology and economy and the optimized summary of technical,
\end{abstract}


biological, sociological and esthetic factors. Thanks to the opportunities allowed by the development of technology, the time of information flow is minimised. The data required for development can be sent smoothly and without any problem from one point of the world to another. But without a suitable recieving attitude this alone would not be sufficient for far away cultures to headway along continents.

Keywords: Japan, design, Fukasawa, Tokujon Yoshioka, Mackintosh, japonisme

\section{Bevezetés}

Európa szerencsés helyzetben van. Az öreg kontinens hagyományos nyitottsága folyamatosan biztosít lehetőséget az állandó megújulásra, a kulturális sokszínüségnek köszönhetően könnyen talál táptalajt gyakorlatilag bármilyen fajta kulturális irányzat. Nem számítanak ritkaságnak azok a szélsőséges vagy extrém lehetőségek sem, melyek biztosítják az európaitól merőben eltérő hagyományokon alapuló kultúrák otthonra találását. Mindezek mellett mégis felvetődik a kérdés, hogy hogyan tudott egy földrajzilag és kultúrájában is elszigetelt ország, mint Japán, ilyen nagy teret hódítani, sőt meghatározó szerepet betölteni Európában és más kontinenseken, háttérbe szorítva még a hagyományosan európai gyökerekkel bíró design irányzatokat is? Milyen módon képes évtizedek óta a világ termék tervezés-és eladás élvonalában maradni, mi több: folyamatosan diktálni az iramot az európai designer közösségnek? Azokat a tervezői és tárgyalkotói attitüdöket igyekszem megfigyelni és összegezni, melyeket elsősorban a kultúrtörténeti és design történeti emlékekből, illetve a kortárs tervezők munkásságából tudok összegyüjteni és rendszerezni. Reményeim szerint olyan eredményekre jutok, melyeket a tervezői gondolkodásomban, a saját stílusom kialakításához hatékonyan alkalmazhatok.

\section{Japonizmus}

1868 előtt Japán - egyrészt földrajzi adottságainak, másrészt társadalmi, illetve ideológiai beállítottságának köszönhetően - szinte teljesen elszigetelten, burokban élte mindennapjait. Ebből kifolyólag történelmük során csak minimálisan keveredtek más népekkel, ami egyéni, kizárólag a szigetország társadalmára jellemző mentalitást és szellemiséget eredményezett.

A kapunyitás következményeként az elzárt kis ország kulturálisan sokszínü világa rászabadult Európára. A beáramló információk nagy hatással voltak Franciaországra, már 1872-1873 között fellelhető volt a Japán iránti rajongás, melynek hatására Philippe Burty megalkotta az új stílus a ,japonisme” azaz japonizmus fogalmát.1875-re megnyílt a Liberity áruház, beszállítója pedig Christopher Dresser volt, aki japán dísztárgyakat, textileket, illetve müvészeti árukat hozott. Népszerüsége tetőfokát a párizsi Exposition Universelle, Nemzetközi kiállításon érte el.

Mindezek hatására megjelentek európai alkotások japán stílusjegyekkel. Erre remek példa Rennie Mackintosh munkássága.

Mindemellett a keleti ország híres képzőművészeti témái, illetve alkotásai hatására az európai müvészek japán stílusú tárgyakat készítettek. Nem volt egyedülálló az sem, hogy pontos másolatokat készítettem

A kanagavai egyezmény után Japán először Amerika majd más nyugati ország felé nyitotta meg kapuit. S bár ezek az egyezmények a nyugat érdekeit szolgálták, ez nem gátolta meg Japán modernizációját. Ez a jelenség pedig a Japán csoda, amely 50 évig tartott és a tudósok a mai napig nem jutottak álláspontra, mi lehetett a gyors fejlődés alapja.

De többek között a széleskörü oktatási reformra gyanakodnak, aminek hála a lakosság 100\%-a írni és olvasni is tudott és a $70 \%$-uk városokban élt. Mindezek kedveztek az óriásvállalatok és a közép-és 
kisüzemek közötti kooperációnak, melynek eredményeként fellendülhettek a határon túli kereskedelmi kapcsolatok.
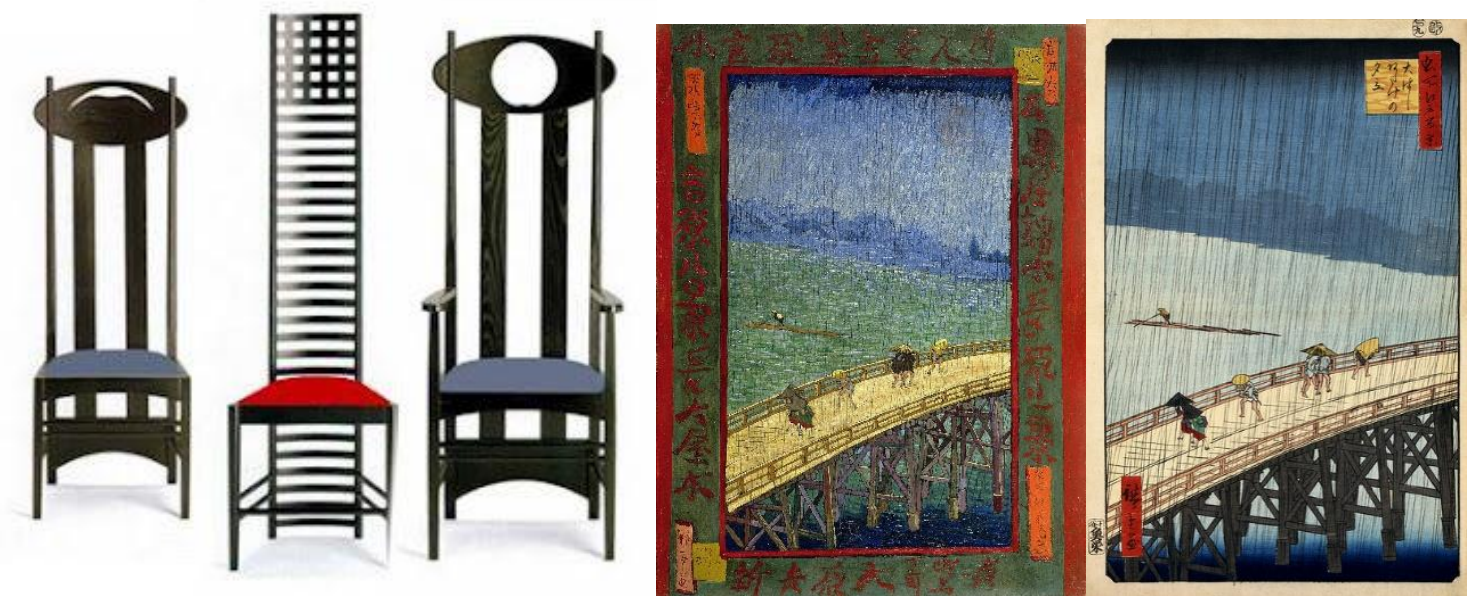

1. ábra. Rennie Mackintosh bútorkollekciójának része 2-3.ábra Hokusai és Van Gogh képe

A más nézetek szerint a filozófiájukban kell keresni a választ. „A japán embernek eszébe se jut, hogy valamit elképzeljen. Nem. Ö megnézi. Azt hiszem, itt kell keresni a japán ember híres szorgalmának titkát.” Ebben a szellemmel érkeztek Magyarországra a 80-as évektől.

Én személy szerint is úgy vélem a japán csoda titka nagy valószínűséggel az a morális, filozófiai és spirituális gondolkodásmód, ami az ő egész kultúrájuknak a nagyon tisztelt alapjait képezi, amihez a mai napig nagyon kevesen mernek hozzányúlni. Ott van minden japánba belekódolva, még azokba is, akik a leglázadóbbak, hogy a természet mindenek feletti tisztelete, illetve az alázat az első. Ez az, ami leginkább jellemzi ezt a kultúrkört.

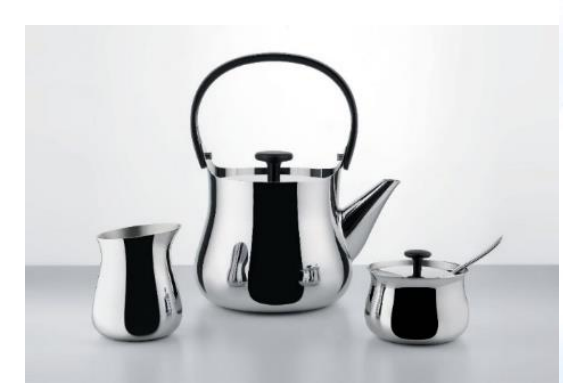

$$
\begin{aligned}
& \text { 4. ábra. Fukasawa konyhai } \\
& \text { design }
\end{aligned}
$$

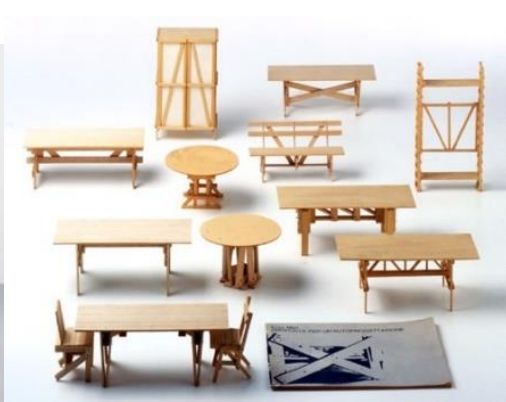

5. ábra. Enzo Mari által tervezett székék

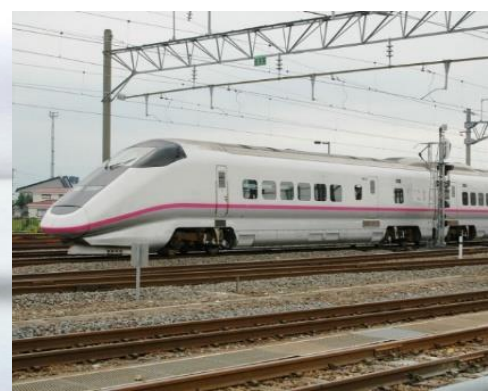

6. ábra. Shinkansen

De bármely nézetet figyelembe is véve a gyors fejlődésnek eredmény a mára már világszerte ismert cégek. Lentebbi felsorolásomban néhány példát hozok rá.

A Hida Sangyo ma a legrégebben müködő Japán bútorgyártó cég. Az 1900-as évek elején a cég alapítója, Masanosuke Sirakawa elindított egy új vállalkozást, amely bükkfából készült bútorokat állított elő. Majd az 1920-as évektől Hida Sangyo Kínába és Koreába exportálta termékeit, majd 1937-től az 
Egyesült Államokba is. E cégnél is felelhető volt az együtt működésre való hajlam, erre remek példa az olasz Enzo Mari tervezővel közösen készült bútorok.

A Muji Japánban az egyik legismertebb kiskereskedelmi társasága. Az 1980-as alapítás óta vezető tervezője Naoto Fukasawa, aki a legelismertebb formatervezők közé tartozott.

\subsection{Közlekedés mely a Japán csoda egyik eredménye lett}

Japánban az elsődleges közlekedési eszköz a tömegközlekedés, mert szervezett és biztonságos mindemellett pontos (Shinkansen, itthon IC-nek hívnák, vonat éves átlag késése $36 \mathrm{mp}$ ). A „szupervonat" tervezője Ekuan Kenji, aki többek között a Yamaha motorkerékpárt is tervezte.

\section{Utak a 20. század második felében}

A második világháború után évekig tartó gazdasági kilengés következett, ami 1948-ra megoldódni látszódott. A szűnni nem akaró nehézségeket nem lehetett ráfogni a háborúra. Új útra volt szükség, ami a japán tervezők szerint az, hogy vissza kell szorítani az iparcikkek dömpingjét és előtérbe kell kerülnie a tradicionális gyökerekkel rendelkező ágazatoknak. Erre jellemző példa az építészet, ahol a metabolista irányzat hódított a XX. század közepétől.

Illetve a Japán müvészetének kevésbé ismert része, a posztmodernbe hajló, élénk díszitő áramlat, ami a 80-as években élte fénykorát, és kiemelkedő szereplője volt Shiro Kuramata. "A modern civilizáció egyik uralkodó premisszája, hogy kerüli az iróniát, a rejtélyt, mindenféle kétértelmü dolgot..." (Ettore Sottsass)

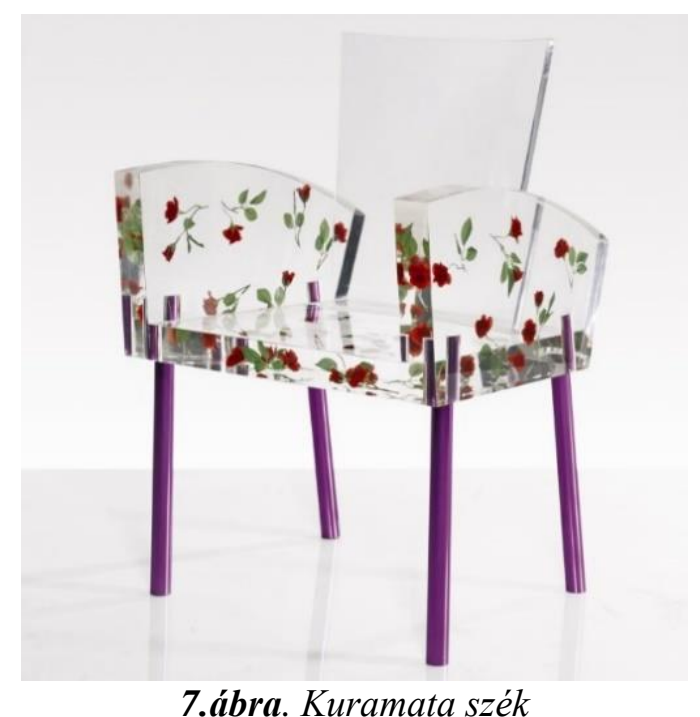

\section{Túl az ezredfordulón}

Japán méltán büszke lehet méltó történetére, hiszen rövid idő alatt érte el a technikai és gazdaságisikerét, átvészelte a II. világháború pusztítását gazdaságilag és lelkileg, majd hihetetlen sebességgel talpra állt, a pénzügyi és a társadalomi helyzetük irigyelt pozícióvá vált a világban. 
Mára a formatervezés világa vált elsődlegesség a tárgyak születésénél. Japán ugyan megtartotta azon nézetét, hogy egy tárgy egyszerü és letisztult alapvetően, de különböző alkotásoknál inkább a gondolatiság került előtérbe.

A Honey Pop fotelt Tokujon Yoshioka tervezésével 2001-ben dobták piacra. Az anyaga selyempapír, amely 120 rétegböl épül fel, különlegessége pedig, hogy a használó is benne van a kreatív folyamatban, hisz ő is részt vesz az alakításban a súlyával.

Átveszik a technikákat, amik Amerikából és Európából erednek és azokat kombinálják az európai és az amerikai technikai, gazdasági, müvészeti eredményeket a japán gondolkodásmóddal. Ami abban áll, hogy a forma funkció és a mondanivaló harmonikus egységben jelenik meg.

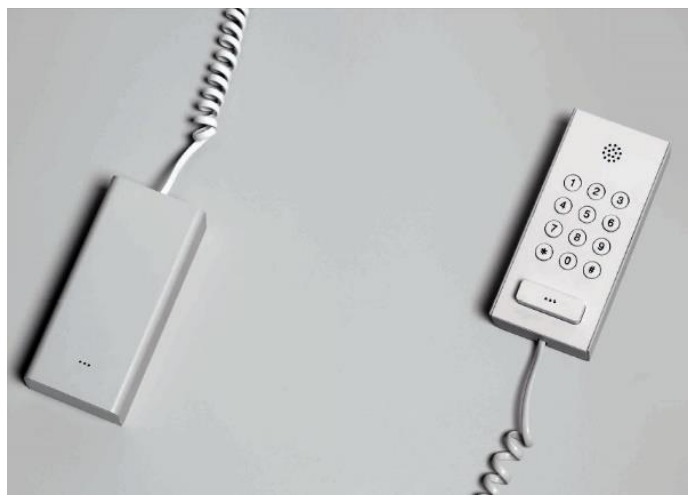

8.ábra. Second Phone

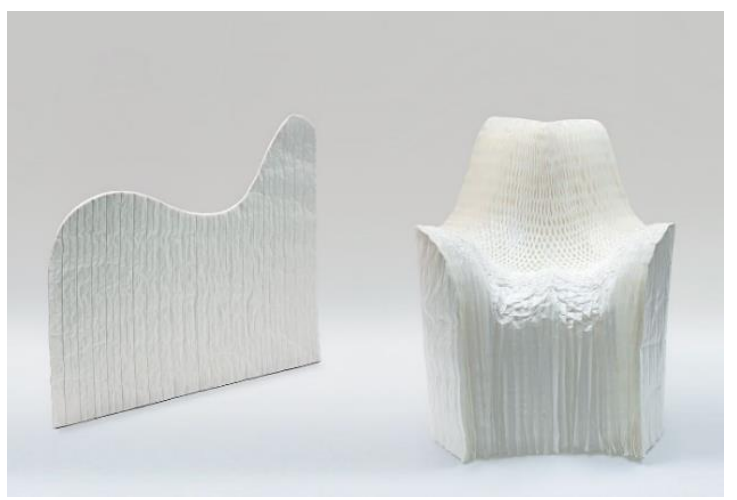

9.ábra. Honey pop fotel

\section{5. Összefoglalás}

Fejlődés vonala a mai napig különbözik az európaitól, okai a gondolkodásmód, kulturális, vallási, filozófiai szemlélet eltéréséből erednek. Az ember-természet viszony nagyon szoros, ezért alázatosan alárendeli magát az ember a természetnek, nem ellene építkezik, mint a nyugati építészetnél ez megszokott. Ebből adódik, hogy ha egy épület elkészül, a természet részévé válik. Ennek szemléletes példája a japán kert kialakítása.
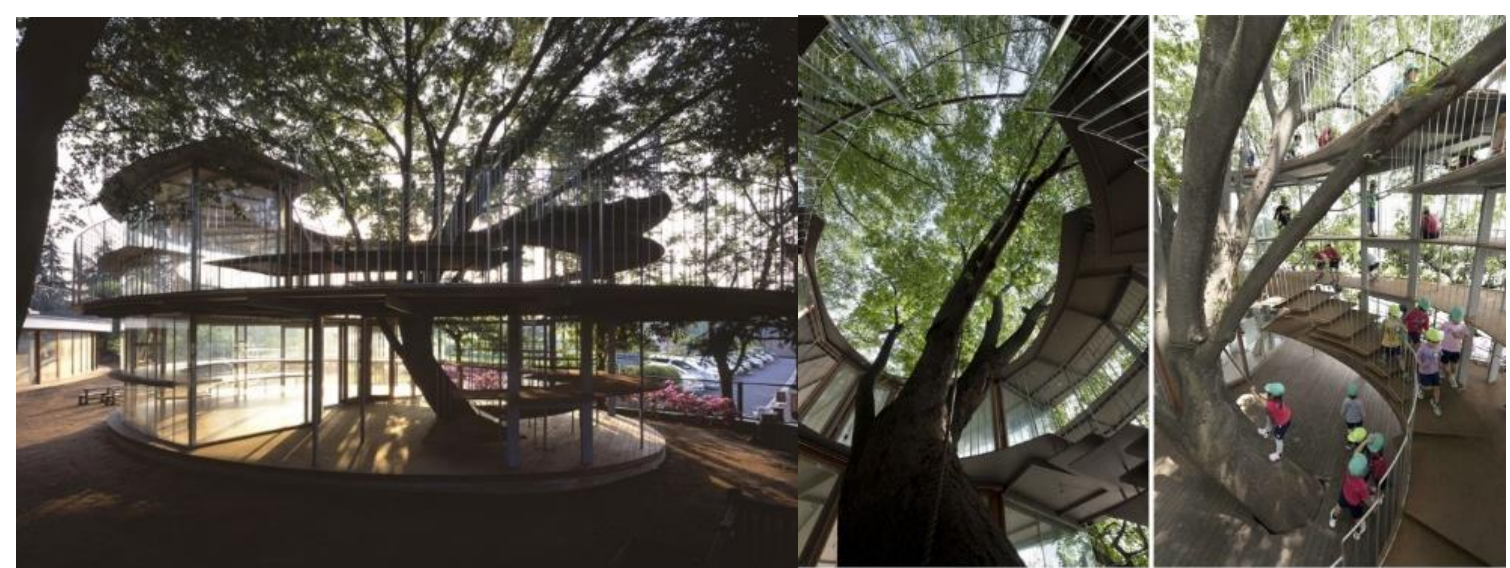

10.ábra. Természet köré épített óvodai játszótér 
A természet alkotta csodákat a japánok rendkívüli módon tanulmányozták. Az ebből adódó lehetőségeket páratlan fegyelemmel és nagy elkötelezettséggel a mai napig alkalmazzák, ez az anyatermészet irányába tanúsított mély alázat valamennyi alkotáson megfigyelhető.

Érthető módon ezek az esztétikai normák inspirálták az európai designer közösséget, így a Japán hagyományőrző jegyeket, technikákat és anyagokat megkísérelték ötvözni az általunk fejlesztett technológiákkal.

Ugyanolyan alázattal viszonyultak a többi ország kultúrájához, mint ahogy a sajátjukhoz. Átvették azokat a megoldási, technikai, gondolkodásmódbeli módszereket, ahol rendelkeznek kulturális háttérrel, ott felfrissítették az európai technikákat a sajátjaikkal, s ezekben a mai napig sikereket érnek el, vitathatatlan az elsőbbségük. Jól egyesítették az új lehetőségeket és a tradicionális módszereket. Ennek hatására több területen is óriási eredményeket értek el, mint például a japán építészetben, divattervezésben vagy a grafika területén.

Amióta átvettek Nyugattól olyan vívmányokat, amik nem rendelkeznek kulturális múlttal, ezekben design értelemben teljesen megrekedtek, nem tudtak újat alkotni a fellendülési időszakon túl.

Ennek ellenére a müszakicikkek területén a japánok úgy értek el eredményt, hogy olcsóbban és többet adtak a vetélytársaiknál, ami nagyon vásárlóbarát termékeket eredményezett. Ennek hatására a világ élmezőnyének tagjait, mint például a Braunt is megelőzték.

Folyamatos versenyben áll a keleti és a nyugati piacgazdaság, ami ma például Amerika és a japán Huawei cég konfliktusában mutatkozik meg.

\section{Köszönetnyilvánítás}

A cikkben ismertetett kutató munka az EFOP-3.6.1-16-2016-00011 jelü „Fiatalodó és Megújuló Egyetem - Innovatív Tudásváros - a Miskolci Egyetem intelligens szakosodást szolgáló intézményi fejlesztése" projekt részeként - a Széchenyi 2020 keretében - az Európai Unió támogatásával, az Európai Szociális Alap társfinanszírozásával valósul meg.

\section{Irodalom}

[1] Yutaka Yazawa: Hogyan éljünk Japánul, Scolar kiadó, Budapest, 2018, ISBN: 9789632449296

[2] Ernyey Gyula: Design, Ráday Könyvesház, Budapest, 2011, ISBN:9789639942059

[3] Mécs Alajos: Az ismeretlen Japán, Terebess, Budapest, 1996, ISBN:9630466902, Letöltve: 2019.03.20

[4] Tagore, Rabindranath: Nacionalizmus, Julius Fischer, Bécs, 1922, Letöltve: 2019.03.20

[5] Conrad-Totman: Japán története, Osiris, Budapest, 2006, ISBN: 9633898404 Letöltve: 2019.03.20

[6] Csendom Andrea: "Japán és az impresszionisták - Az ukiyo-hatás: A Japánizmus a 19. század második felében, és Vincent van Gogh arlesi „Japánja”"(“Japan and the Impressionists - The Ukiyo Effect"), Letöltve: 2019.03.20

[7] Farkas Ildikó szerk.: Ismerjük meg Japánt! (Budapest, ELTE Eötvös Kiadó,2009.), Letöltve: 2019.03.20

[8] Marcus Fairs Design a 21. században, Alexandra kiadó, Pécs, 2007, ISBN: 9633703106 